\title{
SLURS AND LEXICAL PRESUMPTION
}

\author{
William G. Lycan \\ University of North Carolina and \\ University of Connecticut
}

\section{Damn! ${ }^{1}$}

1. What does damn mean when thus uttered in isolation? Perhaps a linguist could show that there is a tacit direct object-we do nearly equivalently say "Damn it" - and possibly that there is a higher subject, "God" (though the latter idea is refuted syntactically by Quang (1971)). The utterance would further be a hortatory subjunctive, "Let/may God damn [whatever]." But that is not the normal use; sincere utterers of "Damn" need not believe in God, nor urge that He actually condemn a particular object to Hell. David Lewis (1972, p. 209) proposed to analyze "Hooray" as "I cheer X," but that was contrived at best; absent syntactic evidence to the contrary, when I shout "Hooray" I have not either asserted a proposition or made a performative utterance having propositional structure.

Unlike hooray, ouch, good gracious, oh, dear, amen, or ha ha, damn can also function as an adjective contributing syntactically to a containing sentence: "That damn cat has pooped in the roasting pan"; "You haven't done a damn thing."2 In such sentences damn is not merely an interjection; "Susan consulted-damn! - a fortune-teller" is fine, but "Susan consulted damn a fortune-teller" is ungrammatical. Likewise for goddam, and as before, "That goddam cat has pooped..." does not (even metaphorically) mean "That cat has been condemned to Hell by God and has pooped...." Goddam is expressive only, despite its quite determinate syntactic role. 
The same applies to fucking; statistically few uses of that word mean anything about sex acts, or indeed anything that contributes to a truth condition.

Following David Kaplan (2004), I shall call such linguistic items-that is, those which are words of particular languages and have syntactic properties but do not seem to contribute to truth-conditional or propositional meaning but only express things - "expressives." They form a surprisingly wide and diverse category, and the term is not felicitous for all of its subcategories. Of recent interest, of course, are slurs and other pejorative expressions.

It must not be simply assumed that slurs are a special case of expressives; we shall consider arguments against that assumption in section $\mathrm{xx}$ below. But I shall begin my exposition with some further words on expressives, in order to introduce my central explanatory notion.

2. I here propose a view according to which expressives work by a particular type of conventional implicature. Other such views have been put forward, as by Potts (2005), Williamson ((2009), (2010)), McCready (2010), Whiting (2013), and Deigan (2013), but, understandably, those authors' ideas of "conventional implicature" are not all the same and do not work in the same ways. -Understandably, because Grice (1975, pp. 44-45) introduced the term without definition in one short paragraph, and used an inappropriate or at least confusing example ${ }^{3}$; the rest of us have each made of it what we will.

What I have made of it (Lycan (1984), Ch. 5) I call “lexical presumption.” Here are some data of the sort that originally motivated my notion.

(1) a. Jane is a sloppy housekeeper and she doesn't take baths either. b. ?!Jane is a neat housekeeper and she doesn't take baths either. [Lakoff (1969) ${ }^{4}$ ] 
(2) a. Jane has just succeeded in proving Goldbach's Conjecture, and her husband is very brilliant too.

b. ?!Jane just added 2 and 2 and got 6 , and her husband is very brilliant too.

(3) a. Jane considered going to the dentist, but decided to enjoy her day off instead.

b. ?!Jane considered taking a pleasant ride through the countryside, having a wonderful dinner, and seeing a movie, but decided to enjoy her day off instead.

(4) a. Jane proved Goldbach's Conjecture and she's smart.

b. ?!Jane proved Goldbach's Conjecture \{but / and yet $\}$ she's smart.

(5) a. Jane is very lucky and very happy.

b. ?! Although Jane is very lucky, she is very happy.

(6) a. Mr. Blifil is sober.

b. ?!Even Mr. Blifil is sober. [Entirely inappropriate when Blifil is the last person one expected to be not sober. $\left.{ }^{5}\right]$

(7) a. Who is Jane?

b. ?!Who is this pebble?

In each case except (7), what is actually said remains constant, but there is an unmistakable difference in implication. Nor is the implication merely a matter of conversational implicature or of relevance-theoretic adjustment, for it is noncancellable in Grice's sense:

(8) *Jane has succeeded in proving Goldbach's Conjecture, and her husband is very brilliant too; you have to be pretty stupid to prove things. 
(9) *Jane considered taking a pleasant ride, but decided to take a pleasant ride instead.

(10) *Jane knows that Goldbach's Conjecture is true but she's smart; of course learning things like Goldbach's Conjecture means you are smart.

(11) *Although Jane is very lucky, she is very happy; mind you, all lucky people are happy.

(12) *Even Mr. Blifil was sober; he's a famous teetotaler.

(13) *Who broke this vase? - a falling lamp, I bet.

3. What explains these noncancellable but seemingly not truth-conditional implications? In each case, what seems to be doing the work is the choice of a certain word: either, too, instead, but, yet, although, even, who. That word cannot be used unless a certain factual assumption is made. If the assumption is not granted, the choice of word is ruled inappropriate. Those words, over and above their truth-conditional meanings, seem to have the sole function of generating their respective implications. As Frege (1892/1966) says: "Subsidiary clauses beginning with 'although' also express complete thoughts. This conjunction actually has no sense and does not change the sense of the clause but only illuminates it in a peculiar fashion" (p. 73). ${ }^{6}$

In what peculiar fashion does such a word illuminate the sense of a clause? According to me (Lycan (1984)), there is a syntactic mechanism that is sensitive to factual presumptions. It is a shallow process, affecting only lexicalization. For example, if it is presumed (by whomever) that the truth of $S_{1}$ is in tension with that of $S_{2},{ }^{7}$ then the occurrence of $\&$ in $S_{1} \&$ 
$\mathrm{S}_{2}$ may be lexicalized as but; otherwise not. In like wise, instead is elliptical for instead of..., and is a surface reflection of $\& \sim$ allowed only when the speaker's set of presumptions includes that one of the relevant alternatives excludes the other.

What is wrong with each of the above " $b$ " sentences is that the lexicalizing process has gone off half-cocked, operated on its own without the requisite trigger. More generally: If a sentence $S_{1}$ lexically presumes a sentence $S_{2}$ and $S_{2}$ is false, then $S_{1}$ will be heard as deviant in a particular way, viz., as mislexicalized. $S_{1}$ contains an inappropriately chosen word, though $S_{1}$ may still be semantically true. ${ }^{8}$

Notice that the syntactic rule does not always merely lexicalize an existing morpheme, as in the cases of instead, but and who. It can simply insert words: too, either, even.

4. I have spoken of factual presumptions. But we can take the category to be wider. It may include normative presumptions, so far as those are taken to be other than factual. Perhaps these: "He played at being department chair"; "President McKinley was assassinated by Czolgosz," and for that matter "McKinley was murdered by Czolgosz" (it is sometimes said that "murder" truth-conditionally means "wrongful killing," but that is not obvious); "Don't send me any more of your rotten papers on conventional implicature." And of course we may further include the expressives with which we began, which are correctly lexicalized only when the appropriate attitude is in place: "That damn cat has pooped in the roasting pan"; "He fucking walked out."

And then there are the isolated, nonpropositional interjections, "Damn!," "Hooray!," "Uh-oh," "Ouch," "Yuck," “Phew," “Oh, dear," "Yee-ha!" et al. These seem to me purely expressive, and to be lexicalized only in a degenerate way. There is no underlying logical form. 
If there is a semantic representation of any kind, it is degenerate too. But, remember, these are determinate words of English and not inarticulate cries. They have interestingly various translations into other languages. ${ }^{9}$

5. And now finally to slurs and other pejorative expressions. ${ }^{10}$ The most obvious examples are racial, ethnic and nationality slurs: nigger, honky, gook, kike, chink, kraut, frog, canuck, limey, septic tank ${ }^{11}$. Others target other groups: bitch, faggot, dyke, geezer, crone, spinster, redneck, cracker, wetback. ${ }^{12}$ Slut is a weaker case, because it characterizes a type of person rather than referring to a particular group. Other pejorative expressions are not slurs, because they do not by themselves target groups or types at all: "That damn cat," "your rotten papers."

(It is interesting that words that are now slurs can have begun quite innocently and only later come to be regarded as derogatory. Abo is now, by Australian liberals, considered a slur on aboriginals, for whom the uncontroversially correct term is still aboriginal. But it is only an abbreviation. Even if we consider it as a diminutive, the "-o" form is just a standard Oz diminutive, used affectionately all the time, thus "Tommo" for "Thomas" instead of the American or British "Tommy." ${ }^{13}$ )

What distinguishes a slur from other expressives and from other pejoratives in particular is that it is semantically a referring expression, denoting a group of some sort, but also having derogatory expressive content. Such “mixed" views have been defended by McCready (2010) and by Croom $(2011,2013) .{ }^{14}$

The position I defend in this paper is that slurs in this sense are semantically (truthconditionally) equivalent to the corresponding nonpejorative terms, and differ from them only 
by lexically presuming a negative normative belief or attitude, typically a derogatory belief or an attitude of contempt. ${ }^{15}$ (I do not think it would be useful to try to say more specifically what the negative content is; I suspect the content details vary with context. Hom (2008) attributes some highly specific noncancellable content to chink, such as "ought to be subject to higher college admissions standards," that is at best highly contextual and, I would say in rebuttal, requires contingent background knowledge for uptake; it is also, in fact, highly cancellable. ${ }^{16}$ )

What recommends the lexical presumption view is that as compared to other accounts of pejoratives, ${ }^{17}$ it is quite simple. It requires neither any departure from standard truthconditional semantics ${ }^{18}$ nor any additional apparatus such as Kaplan's (2004). In fact, it does not require even further elaboration, but only some replies to objections.

6. Bach (1999) (cf. Carston (2002)) maintains that there is no such thing as conventional implicature in the first place. That would be an objection, all right, assuming as I have that lexical presumption is a species of conventional implicature. Bach argues that words like but do not always scope out of indirect quotation:

(14) Marv said that Shaq is huge but he is agile.

And he puts forward a principle he calls "the IQ test" (p. 340): "An element of a sentence contributes to what is said in an utterance of that sentence if and only if there can be an accurate and complete indirect quotation of the utterance (in the same language) which includes that element, or a corresponding element, in the 'that'-clause that specifies what is said." Thus, the contrastive implication of but is attributed to Marv, not undertaken by the speaker, and it contributes to what was said by Marv. 
Secondly (pp. 345ff), Bach assimilates conventionally-implicating words to nonrestrictive relative clauses, appositives, and parentheticals: “Ann's computer, which she bought in 1992, crashes frequently." "Beth's husband, a plumber, never washes the dishes." "Shaq is huge, and, unlike most huge people, he is agile." Though such secondary materials are intuitively not asserted and are not the main points of their respective utterances, they are obviously truthconditional and the speaker is however secondarily committed to their truth. They are said.

Bach maintains that a sentence containing a conventionally-implicating word expresses two separate propositions, as opposed to their conjunction, one secondary and not much influencing people's judgment of the sentence's truth-value. (He spends some time bashing the idea that a sentence can express only one proposition at a time.)

But it should be noted that conventional-implicature views entirely agree with that, except so far as "express" is meant to contrast with "noncancellably implicate." Of course there are two propositions, one primary and carrying the burden of truth assessment, the other secondary and requiring at least a little backing-up or circumlocution if one wants to resist it. That was precisely Grice's view. The question is whether Bach's two arguments against Grice succeed.

Vs. the IQ test: First, Bach's data are disputed by Anderson and Lepore (2013, p. 35), who are officially neutral but rather think that but et al. damn well do scope out of all embeddings including those of indirect speech. I myself think sentences such as (14) can be heard either way depending on intonation, but that does not show that each of those understandings is semantically correct. ${ }^{19}$ Moreover, second, I believe that the IQ test's biconditional, specifically Bach's sufficient condition, is too strong. Even if we grant that (14) 
has a correct narrow-scope reading, it should not follow that Marv's contrastive implication was said. Marv did not say that being huge tends to inhibit being agile.

Bach's point about his assimilations (which have become quite common in the conventional-implicature literature, notably in Potts (2005)) is easily rebutted by me, because they do not apply to lexical presumptions in particular. I completely agree with Bach that nonrestrictive relatives et al. are compositional, thoroughly truth-conditional, and said..$^{20}$ But the same is not true of lexical presumptions, which are by definition not compositional and according to my view, not truth-conditional either.

7. Kaplan (2004) revisits Dummett's (1973) question of logical validity, though in modeltheoretic terms rather than Dummett's inferentialist ones. He points to an intuitive difference between "That damn Kaplan was promoted / $\therefore$ Kaplan was promoted" and "Kaplan was promoted / $\therefore$ That damn Kaplan was promoted"; the former is intuitively valid but the latter intuitively invalid. ${ }^{21}$ Kaplan argues that we should reconsider our notion of logical consequence, and not simply define it in terms of truth-preservation. He goes on to develop a notion of "semantic information" that includes both descriptive or factual content and expressive content.

But there is here no objection to the lexical presumption theory of pejoratives, for the same issue arises in ordinary, nonpejorative cases of lexical presumption. "Mr. Blifil was sober / $\therefore$ Even Mr. Blifil was sober." "Jane just added 2 and 2 and got 6 , and her husband is very brilliant $/ \therefore$ Jane just added 2 and 2 and got 6 , and her husband is very brilliant too." The conclusions carry information that the premises did not. Whatever is the best solution to 
Kaplan's puzzle about validity, it will apply equally to lexical presumption examples. Indeed, that tends to confirm the view that pejoratives are cases of lexical presumption.

8. Williamson (2009) anticipates a very pertinent objection to any conventionalimplicature approach: that since implicature of any sort is a matter of what is communicated by a public speech act in a social context, an account featuring it will not carry over to silent, private thought; yet we can and do think pejoratively. (A similar point afflicts implicature theories of metaphor (Lycan (2006)); and obviously there are sarcastic and other ironic thought as well.)

I do not entirely understand Williamson's reply. He maintains that pejorativeness is still essentially communicative, and that there are communicative phenomena in thought, "in silent communication with oneself" (p. xx26xx); "one manipulates the rhetorical effect of one's own thoughts on oneself." I cannot tell whether Williamson thinks there is a deeper level of thought that is flatly literal and merely propositional. But this is a genuine issue that deserves at least a long separate discussion: communicative phenomena in thought that are not literally communicative. Being a general issue, it does not afford a specific complaint against the lexical presumption theory of pejoratives.

9. My view is a species of what Hom (2008) and Croom (2011) call "pragmatic minimalism": A slur has a descriptive meaning given by its truth-conditional intension, and/but it also conventionally implicates something derogatory. ${ }^{22}$ Hom and Croom offer three objections to such accounts. First, "since the pragmatic mininmalist holds...that the terms African American and nigger have the same literal meaning,... they seem committed to the 
view that racist claims such as "African Americans are niggers" literally express analytic truths that are knowable a priori" (Croom, p. 352).

Second, since conventional implicatures are not cancellable, "[d]erogation ought to occur in every context of use for epithets without any means for cancellation" (Hom, p. 424). But at least in cases of "appropriation," genuine and felicitous uses of slurs are not derogatory. Third, slurs are sometimes felicitously applied to individuals who are not members of the official extension. Nigger has occasionally been applied to white people, and faggot to heterosexual men. (Croom, p. 352)

These objections may have force against some instances of pragmatic minimalism, but they have none against my version. Ad the first, on the lexical presumption view, a slur and its neutral counterpart do not have the same literal meaning, but only the same truth-conditional contribution. One might as well say that "If Mr. Blifil was sober, then even Mr. Blifil was sober" is analytic; cf. our discussion of Kaplan on valid inference (section 7 above).

The second objection needs answering, I agree; that will be the work of section 12 below.

The phenomenon that prompts the third objection is real, certainly, but at least in each case cited by Croom, the use of the slur is clearly analogical predication. When someone speaks of "white niggers," s/he is analogically transferring the nigger stereotype to white people who uncharacteristically fit it. And so for faggot and the gay male stereotype.

10. Difranco (2015) unveils a new class of data: There are slurs that are not single words but have compositional structure. Slanty-eyed, raghead, jungle bunny, trailer trash, curry muncher (that last was a new one on me). 
DiFranco has an iconoclastic purpose: he means to oppose the received view that every slur has a neutral counterpart to which it is truth-conditionally equivalent to that of its neutral counterpart. He argues that his compositional slurs are counterexamples, precisely because they are compositional. For example, slanty-eyed truth-conditionally means having eyes with epicanthic folds, or at least eyes that slant, but the slurring use of that term does not literally entail concepts of those kinds.

I have no complete reply to this. It seems clear that the slurring uses of such compositional terms are idioms. Just as kicked the bucket entails nothing about a(n actual) bucket, jungle bunny entails nothing about a(n actual) jungle, and certainly nothing about bunnies. But I know of no particularly good tests for idiomhood, and so I cannot show decisively why DiFranco's apparently compositional examples are not after all compositional.

11. Anderson and Lepore (2013) make two objections to conventional-implicature accounts of slurs. First, like Bach and Potts they appeal to the assimilation of conventionalimplicature terms to complex compositional constructions, which as we have seen does not apply to the lexical presumption account.

Second, they cite "inert" sentential (not conversational) contexts, a paradigm of which is direct quotation. Inside direct quotation, seemingly, all forms of meaning or content are neutralized: "She said 'Familiarity breeds attempt'”; “He said, 'We're all cremated equal"”; and of course we are reminded by Davidson (1986) that Mrs. Malaprop spoke of a "nice derangement of epitaphs." If I quote someone as uttering (4b) above, I in no way commit 
myself to there being a contrast or tension between proving Goldbach's Conjecture and being smart. Yet slurs project their offensiveness even out of direct quotation, just as do taboo words. (Thus even if Bach is right that conventionally-implicating words sometimes fail to scope out of speech contexts, slurs are not among those that do.)

To that I reply that so far as slurs do project their offensiveness, then not all forms of content have been neutralized. Slurs imply such properties as contemptibility, or at least they conventionally express the speaker's contemptuous attitude.

Anderson and Lepore anticipate and consider an objection to their own view (which view is that slurs are taboo words, offensive because they are prohibited, not the other way $\operatorname{around}^{23}$ ): Hornsby (2001), Richard (2008) and Hom (2008) have claimed that there are inoffensive, nonderogatory, nonslurring uses of slurs, such as

(15) He is not a nigger. [Metalinguistic negation, meant to chide a racist speaker who has used the word. ${ }^{24}$ ] [Hornsby, p. 129]

(16) He said that I was a nigger. [Spoken by an African-American.] [Richard, p. 13]

(Or better,

(17) He called me a nigger. )

(18) Institutions that treat Chinese people as chinks are racist. [Hom, p. 429]

If these uses are indeed inoffensive, that embarrasses Anderson and Lepore's view that slurs are simply taboo words whose prohibitedness projects out of any linguistic context. Unfortunately, it also would impugn the lexical presumption account, since according to that 
account, lexical presumptions are carried by particular words and are part of those words' meanings.

Anderson and Lepore make one general response on their own behalf, and one concession (p. 41). The response is that even (15)-(18) are at best iffy and ill-chosen and should not be used in print or other formal contexts. "Reporters do not usually get a pass." They go on to cite famous cases (see again Kennedy (2002)) in which a speaker used a slur when it was very clear he did so in critique of racist etc. views and with no intention to offend, but did seriously offend and suffered consequences.

However, notice that Anderson and Lepore have played on the fact that (15)-(17), at least, feature a word that in contemporary America is considered the worst of slurs and taboo indeed. If they had used "frog" or "limey," the intuition would not be nearly as strong.

Still, to the extent that "frog" and "limey" are offensively pejorative, they are iffy and illchosen and should not be used at least in print. I am inclined to agree with Anderson and Lepore's judgment. (But see section 13 below.)

Their concession is that "appropriation" or reclamation of a slur such as nigger, $d y k e$ or queer can render its uses, at least by members of the relevant oppressed groups in particular contexts, unpejorative and even positive. This phenomenon merits a section unto itself.

12. First we must distinguish it from that of mock insult as between close friends (Culpeper, 1996). Such friends can rail at each other using offensive terms without giving offense, indeed sometimes deepening their friendship. "That's just like you, you evil shit" (said with a smile). Slurs of course can be used in this way. But that is not the reclamatory use that Anderson and Lepore (following others such as Tirrell (1999)) have conceded. N.b., contra 
Croom (2011, pp. 350, 352), it is a derogatory use. Evil shit, nigger, faggot and such are flatly derogatory terms, and mock insults are mock insults. The moral is, again, that among close friends, derogatory terms can be wielded without actually giving offense. But let us turn to reclamation proper.

Given the above qualification ("at least by members..."), it seems beyond dispute that reclamation happens. Moreover, a reclamation project can in principle succeed globally, in such a way that what has been a slur becomes no longer a slur. Sometime during the 1960s, African-Americans (then politely called "Negroes") reclaimed black, which had been a slur, under the slogan "Black is beautiful," and I believe black is now still no slur though AfricanAmerican may be preferred. Queer is doing reasonably well, as nowadays anyone may refer to the field of queer studies or to queer culture or to queer issues; but it would still be quite offensive to refer to a gay couple as "a pair of queers." (The noun seems to be worse than the adjective.)

An interesting current case is that of the controversy over the Washington Redskins' name. Liberals have complained for some years that redskin is a slur. Certainly its original use was not a polite one, though I do not believe it was ever in a class with nigger or kike. But it is clear that the Washington football team's appropriation of it was indeed an appropriation, i.e., an attempt at reclamation. As Paul Calobrisi (co-founder of www.savethewashingtonredskins) has put it, "Cowboys and Indians, we were the Indians." ${ }^{25}$ But the team's management, staff and players are not the targeted group, so the reclamation is vicarious, which is generally not allowed. ${ }^{26}$ 
Anderson and Lepore suggest, reasonably, that taboos can be relativized to groups and that exceptions can sometimes be made by members of targeted groups for nonmembers (pp. 42-43). But as always they insist this is not a matter of meaning or other content.

On the lexical presumption view, the presence or absence of a presumption is indeed a matter of conventional meaning, though not of truth-condition, so pejorativeness is part of meaning. Therefore, I contend that a successful reclamation project produces a meaning change. ${ }^{27}$ The nonslurring user of what would otherwise be a slur is speaking in an at least slightly different dialect from that of the surrounding majority. The slur does not mean in her/his mouth what it does in mainstream dialects (though as always it has the same truthcondition). -Nor is this response at all ad hoc; the lexical presumption view originally and always has been, in part, that lexical presumptions are elements of an expression's meaning. Anderson and Lepore object (p. 42) that an ambiguity view "fails to explain why nonmembers cannot use a second sense. If it were just a matter of distinct meanings, why can't any speaker opt to use a slur non-offensively?"

Good question, but I believe the answer is that some dialects themselves are closely guarded by the self-conscious and sensitive groups whose distinctive dialects they are. Such a group inhabits one of the islands that make up North Carolina's Outer Banks. ${ }^{28}$ I shall call them "Ur-islanders." They are roughly descendants of the original European settlers of the island ca. 1750 , chiefly pilots and other seafaring people, though by no means all such descendants qualify as Ur-islanders. The Ur-islanders keep very much to themselves and do not willingly interact with other inhabitants of the island, not even with those who are themselves of the old families and may have lived on the island for several generations. The latter do the jobs that 
involve dealing with the mainly tourist public-shopkeeping, running restaurants and fishing tour boats, etc. The Ur-islanders pursue solitary activities, mainly fishing but also gardening, hunting and a little trading. They are all too aware that the island's economy is now based almost entirely on the tourist trade, and they want no part of that except for the income that derives from selling their catch and produce to the island's distributors.

The Ur-islanders speak a highly distinctive dialect. It is one of the many dialects found in pockets of the American southeast that popular culture has claimed survives straight from the Globe Theatre, but in fact it derives primarily from the south and west of England, with a bit of Irish, some mainland U.S. southern vowels, and some $18^{\text {th }}$-century Native American vocabulary mixed in. It is a fascinating dialect to hear.

Sometimes a non-Ur- inhabitant (less often, a regular tourist visitor) will decide to try to build a bridge to the Ur-islanders, in the interest of wider community, and will start by identifying one or more particular Ur-islanders, doing what it takes to make their acquaintance and trying to get to know them. In recent years this has sometimes worked, and cautious friendships have developed. But suppose the bridge-builder were bonhomously to accost her/his new acquaintance and make an attempt at Ur-islandish, using Ur-islandish vocabulary and affecting the accent. That would still be very offensive. Possibly this is because it would be heard as mockery, but it is more because a non-Ur-islander is simply not part of the Urislanders' community and has no right to presume on their dialect. ("Hey, I'm one of you!"“No, you're [Ur-island expletive] not," implication "...and you should have known that.") You can see where this is going. Contra Anderson and Lepore, a dialect difference is not just one of distinct meanings. It need not be one of distinct meanings at all. Nor is it confined 
to pejoratives; it may not even include them. What offends is, presuming to speak the protected dialect that is not one's own. And that is what a well-meaning, nonracist user of nigger is doing when s/he attempts to express solidarity with American black people who use it among themselves. ${ }^{29}$

13. In the spirit of (14), (17) and (18) above, Hom (2012) offers more challenging examples of alleged narrow-scoping pejoratives, in which the pejorative implications are displaced from the speaker.

(19) John is not a bastard. (He's extremely nice.) [p. 387]

(20) If John fucks up another case, then he will be fired. (But I don't think he will because he's working much harder now.) [p. 388]

(21) My father told me that I could not marry that damn Brad. [ibid.; Kratzer (1999)]

(22) I'm not prejudiced against Caucasians. But John, who is, \{thinks / claims $\}$ that you are the worst honky he knows. [ibid.]

(19) is a straightforward case of factual denial, combined if you like with (cf. (15) above) metalinguistic negation directed upon the expressive lexical presumption of bastard over and above the literal extension of, mean and unscrupulous person. (20) seems to me plainly widescoping; the pejorative is still in the speaker's mouth. The speaker's qualification continues it, and does not displace it: "I don't think he will fuck up another case...."

(21) and (22) cause the real problem, and I agree it is one. Damn in (21) is obviously in the father's mouth and not in the speaker's; ditto honky and John in (22). Both smack of direct 
quotation. Indeed, if direct quotation were not intended, the speaker would after all be responsible for the pejorative. It seems, then, that contra Anderson and Lepore, pejorativeness can be nullified by embedding. Yet it was supposed to project even out of direct quotation.

Again, I agree with Hom that there is a puzzle here. But the present question is, whether the puzzle afflicts the lexical-presumption theory of slurs in particular. It does not. For the same puzzling constructions displace undisputed lexical presumptions; in the following sentences, the presumptions are not, or not obviously, taken over by the speaker.

(23) My father told me that Jane is a neat housekeeper and she doesn't take baths either.

(24) My father told me that Jane just added 2 and 2 and got 6 , and that her husband is very brilliant too.

(25) My father told me that although Jane is very lucky, she is very happy.

(26) You and I know that Mr. Blifil is as teetotal as they come, but John said that even Blifil was sober.

(27) That crazy John said that Jane considered taking a pleasant ride [etc.] but decided to enjoy her day off instead.

I do not much like (23)-(27). But I do not like (21) or (22) either, for much the same reasons. There is a nearly perfect parallel between Hom's pejorative cases and standard examples of lexical presumption ${ }^{30}$-thus once again confirming the lexical presumption view of pejoratives. $^{31}$ 


\section{References}

Anderson, L., and E. Lepore, 2013. Slurring words. Noûs 47, 25-48.

Bach, K., 1999. The myth of conventional implicature. Linguistics and Philosophy 22, 
327-66.

Barker, S., 2003. Truth and conventional implicature. Mind 112, 1-33.

Blakemore, D., forthcoming. Slurs and expletives: a case against a general account of expressive meaning. Language Sciences $\mathrm{xx}$.

Carston, R., 2002. Thoughts and Utterances. Basil Blackwell, Oxford.

Croom, A.M., 2011. Slurs. Language Sciences 33, 343-58.

Croom, A.M., 2013. How to do things with slurs: studies in the way of derogatory words. Language and Communication 33, 177-204.

Culpeper, J., 1996. Towards an anatomy of impoliteness. Journal of Pragmatics 25, 349-67.

Davidson, D., 1986. A nice derangement of epitaphs. In: E. Lepore (ed.), Truth and Interpretation: Perspectives on the Philosophy of Donald Davidson. Basil Blackwell, Oxford.

Deigan, M., 2013. Slurs and Conventional Implicature. MS, University of North Carolina.

DiFranco, R., 2015. Slurring with Words and Gestures. Doctoral dissertation in progress, University of Connecticut.

Dudman, V.H., 1984. Conditional interpretations of if-sentences. Australian Journal of Linguistics 4, 143-204.

Dummett, M., 1973. Frege: Philosophy of Language. Duckworth, London. 
Fesl, E., 1986. 'Aborigine' and 'aboriginal'. Aboriginal Law Bulletin 39, 10.

<http://www.austlii.edu.au/au/journals/AboriginalLawB/1986/39.html>.

Frege, G., 1892/1966. On sense and reference. Reprinted in: P. Geach and M. Black (Eds.), Translations from the Writings of Gottlob Frege. Basil Blackwell, Oxford.

Frege, G., 1979. Posthumous Writings. Ed. H. Hermes, F. Kambartel and F. Kaulbach, trans. P. Long and R. White. Basil Blackwell, Oxford.

Grice, H.P., 1975. Logic and conversation. In: D. Davidson and G. Harman (Eds.), The Logic of Grammar. Dickenson, Encino, CA. Also in: P. Cole and J.L. Morgan (Eds.), Syntax and Semantics, Vol. 3: Speech Acts. Academic Press, New York. Page references are to the latter. Reprinted in Grice, 1989: Studies in the Way of Words. Harvard University Press, Cambridge, MA.

Hedger, J., 2012. The semantics of racial slurs: using Kaplan's framework to provide a theory of derogatory epithets. Linguistic and Philosophical Investigations 11, 74-84.

Hom, C., 2008. The semantics of racial epithets. Journal of Philosophy 105, 416-40.

Hom, C., 2012. A puzzle about pejoratives. Philosophical Studies 159, 383-405.

Horn, L., 1985. Metalinguistic negation and pragmatic ambiguity. Language 61, 121-74.

Hornsby, J., 2001. Meaning and uselessness: how to think about derogatory words. In: P. A. French and H. K. Wettstein (Eds.), Midwest Studies in Philosophy XXV: Figurative Language. Basil Blackwell, Oxford. 
Kaplan, D., 2004. The meaning of ouch and oops. Howison Lecture in Philosophy delivered at the University of California, Berkeley, transcribed by Elizabeth Coppock.

Kennedy, R., 2002. Nigger: The Strange Career of a Troublesome Word. Pantheon, New York.

Kratzer, A., 1999. Beyond ouch and oops: how descriptive and expressive meaning interact. Handout for Cornell conference on theories of context dependency, Cornell University.

Lakoff, G., 1969. Presuppositions and relative grammaticality. In: W. Todd (Ed.), Philosophical Linguistics, Series 1. Great Expectations, Evanston, IL.

Levinson, J., 2000. Presumptive Meanings: The Theory of Generalized Conversational Implicature. MIT Press, Cambridge, MA.

Lewis, D.K., 1972. General semantics. In: D. Davidson and G. Harman (Eds.), Semantics of Natural Language. D. Reidel, Dordrecht.

Lycan. W.G., 1984. Logical Form in Natural Language. Bradford Books / MIT Press, Cambridge, MA.

Lycan, W.G., 2001. Real Conditionals. Oxford University Press, Oxford.

Lycan, W.G., 2006. Consumer semantics to the rescue. Presented in a symposium in honor of Distinguished Woman Philosopher Award recipient Ruth Garrett Millikan, Society of Women Philosophers (American Philosophical Association).

McCready, E., 2010. Varieties of conventional implicature. Semantics and Pragmatics 3, 1-57.

Neta, R., 2013. What is an inference? In: E. Sosa and E. Villanueva (Eds.), Epistemic Agency: Philosophical Issues 23, 388-407. 
Potts, C., 2005. The Logic of Conventional Implicatures. Oxford University Press, Oxford.

Potts, C., 2007. The expressive dimension. Theoretical Linguistics 33, 165-97.

Price, R., 2003. A Whole New Life: An Illness and a Healing. Scribner, New York.

Quang, P.D., 1971. English sentences without overt grammatical subject. In: A.M. Zwicky, P.H. Salus, R.I. Binnick and A.L. Vanek (Eds.), Studies Out in Left Field: Defamatory Essays Presented to James D. McCawley. Linguistic Research, Inc., Edmonton.

Richard, M., 2008. When Truth Gives Out. Oxford University Press, Oxford.

Roberts, C., 1996. Information structure in discourse: towards an integrated formal theory of pragmatics. In: J.H. Yoon and A. Kathol (Eds.) Ohio State University Working Papers in Linguistics, Volume 49: Papers in Semantics. Columbus, $\mathrm{OH}$.

Saka, P., 2007. How to Think about Meaning. Springer, Dordrecht.

Tirrell, L., 1999. Derogatory terms: racism, sexism, and the inferential role theory of meaning. In: C. Hendricks and K. Oliver (Eds.), Language and Liberation: Feminism, Philosophy, and Language. State University of New York Press, Albany.

Whiting, D., 2013. It's not what you said, it's the way you said it: slurs and conventional implicatures. Analytic Philosophy 54, 364-77.

Williamson, T., 2009. Reference, inference, and the semantics of pejoratives. In: J. Almog and P. Leonardi (Eds.), The Philosophy of David Kaplan. Oxford University Press, Oxford.

Williamson, T., 2010. The use of pejoratives. In: D. Whiting (Ed.), The Later Wittgenstein on Language. Palgrave Macmillan, Basingstoke, UK. 
Wolfram, W., and N. Schilling-Estes, 1997. Hoi Toide on the Outer Banks: The Story of the Ocracoke Brogue. University of North Carolina Press, Chapel Hill.

Yalcin, S., 2013. Dynamic Semantics. In: G. Russell and D. Graff Fara (Eds.), Routledge Companion to Philosophy of Language. Routledge, London.

\section{Footnotes}

\footnotetext{
${ }^{1}$ Alert readers will have recognized this opening as an allusion to Dorothy Sayers' first novel, which famously began: “'Oh, damn!' said Lord Peter Wimsey at Piccadilly Circus” (often misquoted as just “'Damn!' said Lord Peter Wimsey").
}

${ }^{2}$ But not "I don't give a damn" or "It doesn't matter a damn." In those, "damn" is a misspelling of dam, a noun, meaning an otherwise useless wad of wet paper or the like used to plug a hole in a metal item being repaired by a tinker.

I conjecture that damn as adjective is a shortening of damned, a participle.

\footnotetext{
3 "He is an Englishman; he is therefore brave," the alleged implicature being carried by "therefore." But "therefore" makes a straightforwardly truth-conditional contribution; it means "for that reason." - Actually that is far too simple; see Neta (2013).
} 
${ }^{4}$ Lakoff offered this and related data in support of his claim that a sentence may be syntactically deviant depending on contingent ways the world might be. Lycan (1984) argued that that is true only in a narrow sense, and that it cannot be used to defend the idea of semantic presupposition.

${ }^{5}$ Cf. Dudman (1984), "Even Grannie is sober." Actually I myself have argued (Lycan (2001), Chs. 5 and 6) that "even" makes a substantive truth-conditional contribution, but this remains a minority position; I here insincerely assume the majority view.

${ }^{6}$ Frege continues: "We could indeed replace the concessive clause without harm to the truth of the whole by another of the same truth value; but the light in which the clause is placed by the conjunction might then easily appear unsuitable, as if a song with a sad subject were to be sung in a lively fashion." A lovely analogy, but inaccurate; the lively singing would be bad interpretation and bad style, but the use of "although" when there is no relevant tension is flatly incorrect.

And cf. Frege's remarks on "tone." He contrasts "cur" with "dog" (1979), though they have not only the same reference but the same sense.

${ }^{7}$ Interestingly, the tension may be of contextually different sorts; see Bach (1999).

${ }^{8}$ Lexical presumption inherits at least six things from Grice's cursory characterization of conventional implicature (ibid.): (i) It is not calculated as conversational implicatures are, but is determined by "the conventional meaning of the words used." (ii) In asserting a sentence that conventionally implicates that $p$, "I have certainly committed myself, by virtue of the meaning of my words, to its being the case that" $p$. (iii) And as noted, that commitment is noncancellable. (iv) But in uttering such a sentence I have not actually said that $p$. (v) Accordingly, my utterance is not "STRICTLY SPEAKING, false" if it is not the case that $p$. (vi) Lexical presumptions are "detachable" in Grice's sense: A sentence $S_{1}$ that presumes $S_{2}$ may be logically equivalent to an $S_{3}$ that does not presume $S_{2}$. 
Some more recent versions of "conventional implicature" are far more ambitious and wide-ranging, most notably those of Potts (2005) and Deigan (2013). Potts includes some phenomena inherited from the confused old "semantic presupposition" literature, such as nonrestrictive relative clauses and such sentence adverbs as "unfortunately." Deigan turns to dynamic semantics, as in Roberts (1996) and Yalcin (2013). N.b., again, none of this is or could be an incorrect account of "conventional implicature"; pragmatics has variously moved on from Grice's paragraph and profitably so.

${ }^{9}$ As do English representations of animal utterances, e.g., "meow," "arf," "baa," "cluck, cluck," and "moo."

${ }^{10}$ Concern with these goes back at least to Dummett (1973).

${ }^{11}$ Old Australian rhyming slang for yank (American). Bluenose is a very old term for Nova Scotians, but I do not know whether it was ever a slur.

${ }^{12}$ For an extensive catalogue, see Saka (2007), p. 144.

${ }^{13}$ I confess I do not see why it is considered a slur, though if it is considered one, it is considered one, and a Google search confirms that it now very definitely is. (I do realize that diminutives can be demeaning, as can even mere abbreviations such as Hebe.) Likewise Chinaman for male Chinese; that is not even a diminutive, and Englishman and Frenchman are hardly slurs. I do not know whether the older, flatter aborigine is regarded as a slur; I have not heard it uttered in some years. Fesl (1986) asks that it be capitalized. Indigenous has been proposed, but is severely controversial among aboriginals themselves.

In fact, the unutterable nigger itself may have come from the if anything extra-polite Negro, meant to replace black before black was reclaimed (see below). In America, it would seem, the " $n$ "" word is just white southern dialect pronunciation of Negro. (I might have said "white southern dumbass," quoting the novelist Dan Jenkins, but that would have been a slur.) Yet the word is very old in the UK, and apparently its origin is unknown (Kennedy, 2002)). For all I know, Negro was a cleaning-up of nigger. 
Interestingly, in recent American writing, the word slave has been used less willingly, in favor of enslaved person and the like-as if it were not tautologous that a slave is a person who has been enslaved.

In some cases it seems no euphemism can succeed. I am thinking of determined liberal attempts to replace handicapped and disabled. Every replacement has quickly become a slur or at least considered offensive. The most recent one I know is differently abled, which is not or not yet a slur, but is so affected that anyone should be ashamed to use it. The moral seems to be that referring at all to the class in question is at least mildly offensive. The late playwright Reynolds Price, crippled by spinal cancer, said (2003) he had never met any handicapped person who was not positively offended by euphemisms. His own preferred term was gimp, but he noted that one of his gimp friends had an excellent euphemism for the non-handicapped: temporarily abled.

${ }^{14}$ Croom (2011) argues painstakingly and decisively against a purely descriptive, nonexpressive account of slurs, though he does not cite anyone as having held such a view. He goes on to criticize purely expressive, nondescriptive accounts, and apparently that needed doing (vs. Kratzer (1999), Potts (2007); and see Hedger (2102)), though as Croom shows, such accounts are simply untenable.

Blakemore (forthcoming) insists that slurs have both descriptive meanings and expressive implications, but argues that the latter are pragmagtically generated through the use of metalinguistic background knowledge. It is interesting that purely expressive common nouns can be invented on the spot, yet easily understood as such. "'Andy! You geck! You gink!' Marcus K. Hoot's voice rang and echoed through the lonely bungalow. 'You locoed bonehead, Andy! Show up, you dog-goned gump!' Mr. Hoot was a little excited." (Lord Billy Bunter, by Frank Richards, Cassell \& Co. Ltd., London, 1956, p. 133.) Slurs can be invented on the spot too, but their intended descriptive content is an aid there both to production and to understanding.

${ }^{15}$ Tirrell (1999) points out that the relevant belief or attitude may not be the speaker's own personal one. It may be only that which has accumulated historically in the speaker's linguistic community. Tirrell argues for a Brandomian social-inferential-role theory of slurs.

${ }^{16}$ Croom (2011, p. 350) makes this point also. 
Saka (2007, p. 148) offers the illuminating suggestion that variation as between slurs in their exact negative implications is due to the differing historical circumstances from which they arose.

${ }^{17}$ For a survey of early views, see Saka (2007), Ch. 5.

${ }^{18} \mathrm{~A}$ very strict truth-conditional theorist would insist that but means exactly the same as and. As I choose to use the "m-"word, that is not so. See section 9 below.

${ }^{19}$ If the narrow-scope readings are semantically sound, that would require a significant syntactic complication in my account of lexical presumption, since the lexicalizing would then not straightforwardly constitute a word choice made by the speaker.

Croom (2011) offers an explanation of why lexical-presumption-generating words do in general scope out: "[T]he choice of which words one accepts as legitimate for use comes prior to the choice of what one will in turn use those words to say, and so the speaker's choice of acceptable terms itself out-scopes their choice of the particular positions in which they choose to place those terms within their utterance" (p. 346).

${ }^{20}$ Lycan (1984) went so far as to maintain that they are conjuncts.

${ }^{21}$ There is an obviously related issue about logical truths: "Either Kaplan is a honky or he isn't," supposed to be intuitively not a logical truth. Here I tentatively share the intuition, but only because I tend to hear the negation as metalinguistic negation in the sense of Horn (1985).

And there is an obviously related issue about T-sentences: they cannot be homophonic. "Kaplan is a honky' is true iff Kaplan is a honky" is offensive, and its RHS would have to be replaced by "Kaplan is a Caucasian." (Which leaves something out, but on the lexical presumption view, nothing about truth.) However, contra Davidson, T-sentences could never have been homophonic in the first place (Lycan (1984), Chs. 2 and 3). Also, as in the case of taboo words, the expressive features of expressives tend to persist through embedding and even through direct quotation. More on this below. 
${ }^{22}$ My lexical presumption view is then closely related to the pragmatic minimalism of McCready (2010).

${ }^{23}$ For extended critique of the view, see Deigan (2013).

${ }^{24}$ Notice that the negation must be metalinguistic. In "Is this Lycan fellow a nigger?" - “No, he's not a nigger," the word is again offensive.

25 "What is a Slur? And Who Decides it is?," article by Jesse Washington, AP National Writer, The Day (New London, CT), June 22, 2014.

${ }^{26}$ On June 18, 2014 the Trademark and Appeal Board decided 2-1 that redskin is "disparaging to Native Americans." They made three general points: (1) That only the views of the targeted group matter; other groups' opinions and attitudes are irrelevant. (2) That a "substantial" proportion of Native Americans must be offended. The judges set the threshold at 30\%. (3) That slurring does not require intent (which neutralizes Calobrisi's undoubtedly heartfelt justification, and which is certainly right). I infer that some sort of poll was conducted and showed that at least $30 \%$ of Native Americans are offended.

Interestingly, to my knowledge no one has complained about the name of the Cleveland Indians (baseball team), though Indians has long been considered politically incorrect and replaced by Native Americans. It does seem that redskin is at least a mild slur in way that Indian is not. I suspect the liberal objection to Indian is only that it is Eurocentric.

${ }^{27}$ In this I am preceded by Tirrell (1999), Kaplan (2004), Saka (2007), Richard (2008), and Hom (2008).

${ }^{28}$ This story is complicated, and in certain fear of factual error I will fictionalize it here. But the known and unknown departures from fact do not matter for my dialectical purposes; a hypothetical community to which my 
fictional description does apply will do as well to make my point. For a more accurate but incomplete account of the real group that inspired the fiction, see Wolfram and Schilling-Estes (1997).

${ }^{29}$ To appeal to meaning change as alone inducing dialect difference would have been only to put the problem off: Of course if two people use the same words with different meanings, then to that extent they speak different dialects; that is tautologous and the reference to dialect adds nothing. One must add, as I have, a story about the significance of dialect difference.

${ }^{30}$ In fact, it is already known that there are what Stephen Levinson (2000) calls "intrusive constructions," operators that yield compound sentences whose truth-conditions depend on conversational implicatures rather than the truth-conditions of the operands: "Driving home and drinking several beers is better than drinking several beers and driving home"; "If each side in the soccer game got three goals, then the game was a draw"; "She either got married and had a child, or had a child and got married; I don't know which"; "Because the police have recovered some of the gold, they will no doubt recover the lot." Carston (2002) argues that Relevance Theory can handle such data even though traditional Gricetheorie cannot.

${ }^{31}$ For incisive and helpful comments on my originally submitted draft, I am indebted to each of two anonymous reviewers for Language Sciences, one of whom went out of her/his way to provide a detailed list of works on the present topic that I had left out of account or never seen at all. I have revised in light of nearly all the referees' comments, but not as thoroughly as I wish I could have. 